\title{
Resistance to Meloidogyne incognita expresses a hypersensitive-like response in Coffea arabica
}

\author{
Erika Valéria Saliba Albuquerque • Regina Maria Dechechi Gomes Carneiro • \\ Poliene Martins Costa • Ana Cristina Meneses Mendes Gomes • \\ Marcilene Santos • Antonio Alves Pereira • Michel Nicole • Diana Fernandez • \\ Maria Fatima Grossi-de-Sa
}

Received: 27 August 2009 / Accepted: 3 March 2010/Published online: 20 March 2010

(C) KNPV 2010

\begin{abstract}
Root-knot nematodes (RKN) are obligate parasite species of the genus Meloidogyne that cause great losses in Arabica coffee (Coffea arabica L.) plantations. Identification of resistant genotypes would facilitate the improvement of coffee varieties aiming at an environmental friendly and costless nematode control. In this work, the $C$. arabica genotype 'UFV 408-28' was found to be resistant to the most destruc-
\end{abstract}

E. V. S. Albuquerque • R. M. D. G. Carneiro • P. M. Costa • A. C. M. M. Gomes • M. Santos • M. F. Grossi-de-Sa Embrapa-Recursos Genéticos e Biotecnologia, Brasília, DF 70849-970, Brazil

A. A. Pereira

CRZM, EPAMIG,

Viçosa, MG 36570-000, Brazil

E. V. S. Albuquerque $\cdot$ M. Nicole $\cdot$ D. Fernandez $(\square)$ IRD - Institut de Recherche pour le Développement, UMR-186 IRD-Cirad-UM2 "Résistance des Plantes aux Bioagresseurs",

BP 64501, Montpellier-Cedex 5 34394, France

e-mail: Diana.Fernandez@ird.fr

E. V. S. Albuquerque · M. F. Grossi-de-Sa

Graduate Program in Cellular and Molecular Biology

(PPGBCM), Center of Biotechnology, Federal University

of Rio Grande do Sul (UFRGS),

91501-970, Porto Alegre, Brazil

E. V. S. Albuquerque

Université de Montpellier II (UM2), Systèmes Intégrés en

Biologie, Agronomie, Géosciences, Hydrosciences,

Environnement (SIBAGHE),

34095, Montpellier, France tive RKN species $M$. incognita. Pathogenicity assays indicated that the highly aggressive populations of $M$. incognita races 1, 2 and 3 were not able to successfully reproduce on 'UFV 408-28' roots and displayed a low gall index $(\mathrm{GI}=2)$. An average reduction of $87 \%$ reduction of the $M$. incognita population was observed on 'UFV 408-28' when compared to the susceptible cultivar 'IAC 15'. By contrast, 'UFV 408-28' was susceptible to the related species $M$. exigua and $M$. paranaensis ( $\mathrm{GI}=5$ and 4 , respectively). Histological observations performed on sections of UFV408-28 roots infected with $M$. incognita race 1 showed that nematode infection could be blocked right after penetration or during migration and establishment stages, at 6 days, 7 days and 8 days after infection (DAI). Fluorescence and bright field microscopy observations showed that root cells surrounding the nematodes exhibited HR-like features such as accumulation of phenolic compounds and a necrotic cell aspect. In the susceptible 'IAC 15' roots, $6 \mathrm{DAI}$, feeding sites contained giant cells with a dense cytoplasm. Necrotic cells were never observed throughout the entire infection cycle. The HR-like phenotype observed in the 'UFV 408-28'-M. incognita interaction suggests that the coffee resistance may be mediated by a $R$-gene based immunity system and may therefore provide new insights for understanding the molecular basis of RKN resistance in perennial crops.

Keywords Coffea arabica $\cdot$ Hypersensitive-like response $\cdot$ Meloidogyne $\cdot$ Resistance .

Root-knot nematode 


\section{Introduction}

Root-knot nematodes (RKN) of the genus Meloidogyne are biotrophic plant parasites with a broad host range encompassing most of the crop plants (Trudgill 1997). RKN form characteristic galls on the root system where they establish, feed and reproduce. Infective second-stage juveniles (J2) of RKN penetrate roots and migrate intercellularly to reach the vascular cylinder where they become sedentary and establish their permanent feeding site (Williamson and Hussey 1996). Via the stylet, juvenile nematodes inject oesophageal gland secretions in five to seven selected undifferentiated pro-cambial host cells, inducing a specialized nourishing site (giant cells) active during their whole life cycle (Bird and Kaloshian 2003). Galling occurs by hypertrophy of these giant cells and probably by cell division within the vascular system. Heavy infection in host plant roots may result in the induction of multiple galls resulting in large and lumpy swellings (Hunt et al. 2005).

Among the non-chemical methods available for managing $\mathrm{RKN}$ in infested crop fields, host plant resistance is a preferred strategy and is an environmentally safe alternative. Nowadays, only a few specific RKN resistance $(R)$ genes have been cloned, notably from tomato, potato, sugar beet and soybean (Fuller et al. 2008). Other RKN-specific $R$ genes have been mapped but remain to be cloned, including the Mex-1 gene conferring resistance to $M$. exigua in coffee (Noir et al. 2003). The plant immune system is modulated by a series of molecular interactions between host and pathogen components (Jones and Dangl 2006). The specific recognition of the pathogen by the plant may lead to a resistance reaction known as the hypersensitive response (HR), accompanied by rapid cell death in and around the initial infection site (Lam et al. 2001). Early HRs have been observed in Mi-1-mediated resistance in tomato (Williamson 1999), Mex-1-mediated resistance in coffee (Anthony et al. 2005), Me3-mediated resistance in pepper (Pegard et al. 2005), and wild peanut (Proite et al. 2008). However, there was no typical HR in the $R k$ mediated incompatible cowpea-RKN interaction, where nematodes failed to reach maturity and did not lay eggs in resistant roots (Das et al. 2008). It is thus likely that several resistance mechanisms are operating to arrest nematode development in plant roots.
One serious problem limiting the production and quality of coffee is the damage caused by RKN infection. The coffee plant (Coffea spp.) is an upright, evergreen shrub from the Rubiaceae family with a long biological cycle. Coffea arabica $\mathrm{L}$. is a species of significant economic importance especially in Latin America. Root infection with Meloidogyne species induces foliar chlorosis, reduces growth, causes leaf fall and a general plant weakening, or even plant death (Campos and Villain 2005). Together, M. incognita and M. paranaensis can cause serious damage in $C$. arabica plantations, destroying up to $80 \%$ of the root system within five years of planting (Bertrand and Anthony 2008). M. incognita race 1 is the most widespread nematode on coffee plants followed by race 3 and 2 in Paraná and São Paulo States in Brazil. M. exigua Goeldi causes 10-20\% drop in yield due to the general weakening of the tree (Bertrand et al. 1997).

Coffee breeding for durable resistance to $\mathrm{RKN}$ is now a major goal in coffee producing countries. A few years ago, a simply inherited major gene (Mex-1) from the related coffee species $C$. canephora was found to control resistance to $M$. exigua in C. arabica (Noir et al. 2003). Upon avirulent RKN infection, Mex-1-carrying coffee plants show HR-like symptoms around 4-6 days after inoculation (DAI) preventing the majority of giant cells to form (Anthony et al. 2005). Recently, in an initial greenhouse screening of C. arabica accessions, the genotype 'UFV 408-28' was identified as putatively resistant to $M$. incognita (Lima, R.D., unpublished data). The objective of the present work was to assess the resistance of 'UFV 408-28' to the main Meloidogyne spp. parasitizing coffee roots. In this study, standard pathogenicity assays showed that the 'UFV 408-28' genotype presented resistance to three highly aggressive races of $M$. incognita. We have then examined the histological alterations in susceptible and resistant coffee genotypes following infection with $M$. incognita in order to study the resistance mechanisms that are operating in roots.

\section{Materials and methods}

Resistance characterization assays

The Coffea arabica plant materials used in this study were the cultivar Catuaí vermelho 'IAC15' (Instituto 
Agronômico de Campinas, São Paulo-Brazil), a susceptible control, and the genotype 'UFV408-28' (derived from Hybrid of Timor CIFC 1590/9, Universidade Federal de Viçosa, Minas Gerais-Brazil).

The populations of root-knot nematodes from coffee were characterized and identified by esterase phenotypes (Est) and SCAR (sequence-characterized amplified region) markers using the methods reported by Carneiro and Almeida (2001) and Randig et al. (2002). The three races of $M$. incognita were characterized according to Hartman and Sasser (1985). We tested six nematode populations from five states in Brazil: $M$. incognita (Est I1) race 1 from Avilândia, São Paulo; M. incognita (Est I2) race 2 from Jaguaré, Espírito Santo; M. incognita (Est I2) race 3 from Londrina, Paraná; $M$. exigua (Est E1) from Bom Jesus de Itabapoana, Rio de Janeiro; $M$. exigua (Est E2) from Lavras, Minas Gerais; $M$. paranaensis (Est P1) from Apucarana, Paraná. The nematode populations used in this work all originated from infected coffee roots. The populations were first multiplied on coffee cv. Catuaí Vermelho 'IAC 15' and then on tomato (Lycopersicon esculentum group Santa Cruz cv. Santa Clara) roots under greenhouse conditions. To recover eggs, 3-month-old tomato roots or 6-month-old coffee roots were cut into $1 \mathrm{~cm}$ to $2 \mathrm{~cm}$ segments and blended for $1 \mathrm{~min}$ in a $0.5 \%$ sodium hypochlorite solution (Boneti and Ferraz 1981). Eggs were rinsed thoroughly and counted in $1 \mathrm{ml}$ aliquots in Peter's counting slide. Single coffee plants, with two or three pairs of leaves, grown in 31 plastic pots, were inoculated with approximately 5,000 eggs of each nematode. The inoculum in water suspension was pipetted around the stem base. Eight replicates were arranged in a randomized block, factorial design. Plants were grown with regular watering and fertilization. Eight months after inoculation, roots were analyzed using the method described by Hartman and Sasser (1985). The number of galls was counted and the gall index (GI) number assigned according to the scale: $0=$ no galls, $1=1-2$ galls, $2=$ $3-10$ galls, $3=11-30$ galls, $4=31-100,5=$ over 100 galls. The final population (FP) was considered as the total number of eggs and second-stage juveniles (J2) per plant, counted under a light microscope using Peter's slides. The reproduction factor (RF) was calculated by dividing the FP by the initial population (IP=5,000 eggs) (Roberts and May 1986). The percentage of population reduction (PR) was calculated by comparing the RF to the susceptible control, using the following formula: $\mathrm{PR}=100-\left(\mathrm{RF}_{\mathrm{UFV} 408-28} / \mathrm{RF}_{\mathrm{IAC} 15} * 100\right)$. Genotypes were classified for resistance or susceptibility using the scale of Moura and Regis (1987): 0$25 \%=$ highly susceptible (HS), $26-50 \%=$ susceptible, $51-75 \%=$ low resistance (LR), 76-95\%=moderately resistant (MR), 96-99\%=resistant (R), 100=immune (I).

Histopathological analysis

The eggs were extracted using Hussey and Baker's methodology (1973) and the hatching of secondstage juveniles (J2) was done using the modified Baermann funnel technique (Whitehead and Heming 1965). The nematode suspension was concentrated in $50 \mathrm{ml}$ Falcon tubes by centrifuging at 3,000 rpm for $5 \mathrm{~min}$. The root systems of coffee plants at the first true leaf stage (3 months to 4 months) were inoculated with approximately $10,000 \mathrm{~J} 2$ per plant. Roots were harvested at 2 days, 4 days, 6 days, 7 days, 8 days, 10 days, 14 days, 28 days, 34 days, and 49 days after inoculation (DAI) and carefully washed. A set of root segments were excised from each plant, immediately stained with acid fuchsine and observed using stereo and light microscopy under bright field optics (Byrd et al. 1983). Another set of 20 root segments was excised from the same plant and fixed and embedded in the epoxy resin Technovit 7100 (Kulzer Friedrichsdorf, Germany) according to Pegard et al. (2005). Around eight embedded samples were sectioned in $4 \mu \mathrm{m}$ slices for each time point. Unstained root sections were mounted on glass slides and fluorescence was observed after UV excitation (UV filter set A2 Zeiss 02; 488002-0000). The same sections were subsequently stained $\left(1 \mathrm{~min}\right.$ at $\left.60^{\circ} \mathrm{C}\right)$ with $0.5 \%$ toluidine blue in $0.1 \mathrm{M}$ sodium phosphate buffer, pH5.5 and observed using a light microscope.

\section{Results}

Root galling and reproduction of Meloidogyne spp.

Six Meloidogyne spp populations were chosen based on their ability to infect coffee: $M$. incognita (Est I1) race $1, M$. incognita (Est I2) race 2, $M$. incognita (Est I2) race 3, $M$. exigua (Est E1), M. exigua (Est E2) and M. paranaensis. The reproductive behaviors of the six 
RKN populations were compared on the 'UFV 40828 ' and the 'IAC 15' genotypes in greenhouse tests (Table 1).

Eight months after inoculation, the gall indexes reached their maximal level (5) for all RKN tested in the cultivar IAC15. In contrast, gall indexes were lower in 'UFV 408-28' for M. paranaensis (4) and, in particular, for the three races of $M$. incognita (only 2 ).

Significant differences concerning the reproduction factor were registered among the RKN species (Table 1). On 'IAC 15', the virulent M. exigua (E1) population reproduced significantly more than all other populations, and M. paranaensis showed the lowest reproduction ability. On 'UFV 408-28', the $M$. paranaensis and $M$. exigua E1 and E2 populations displayed the same reproduction capacities as on 'IAC 15'. However, the population of virulent $M$. exigua reproduced significantly better than the avirulent population on both coffee genotypes. The $M$. incognita populations were significantly reduced on 'UFV 408-28' when compared with 'IAC 15'. The percentage reduction in the reproduction of $M$. incognita races 1, 2 and 3 ranged from $86 \%$ to $89 \%$ on UFV 408-28 (Table 1).Together, these results led us to conclude that the 'UFV 408-28' genotype can be defined as i) moderately resistant (MR) to $M$. incognita, ii) highly susceptible (HS) to M. exigua, and iii) susceptible (S) to M. paranaensis (Table 1).
Histological response to infection

Histological features from approximately 9,000 root sections were observed in both susceptible (Fig. 1) and resistant (Fig. 2) C. arabica genotypes inoculated with $M$. incognita race 1 . Nematode-infected roots were compared with non-inoculated controls (data not shown).

\section{The compatible interaction}

Microscopic observations of the infected 'IAC 15' root sections showed that the penetration of $\mathrm{J} 2$ in 'IAC 15' was detected starting from 2 DAI in the apical meristem (Fig. 1a) and many J2 were observed within the root at 6 DAI. From 6 DAI to 49 DAI, we detected the presence of nematodes in the root cortex (Fig. 1a), elongation zone (Fig. 1c) and vascular cylinder (Fig. 1b, d, e, f). Feeding sites were mainly observed from 6 DAI on (Fig. 1b, c, and d). Dividing and asymmetrical perivascular cells were observed (Fig. 1b, c, d, e, and f), pushing the cortex outwards and causing the enlargement of the roots. Infected roots of 'IAC 15' had around 5 well defined giant cells associated to each nematode at 6 DAI (Fig. 1b). Giant cells were hypertrophied, oval shaped, and presented a highly vacuolated and dense cytoplasm containing various nuclei (Fig. 1b, c and d). As galls developed, (14DAI) juveniles enlarged and apparently

Table 1 Gall index (GI), reproduction factor (RF) and percentage of population reduction (PR) of Meloidogyne spp. in C. arabica 'IAC 15 ' and 'UFV 408-28' genotypes at 240 days after inoculation

\begin{tabular}{|c|c|c|c|c|c|c|}
\hline \multirow[t]{2}{*}{ RKN species } & \multicolumn{2}{|c|}{ IAC 15} & \multicolumn{4}{|c|}{ UFV 408-28 } \\
\hline & $\mathrm{GI}^{\mathrm{a}}$ & $\mathrm{RF}^{\mathrm{b}}$ & $\mathrm{GI}^{\mathrm{a}}$ & $\mathrm{RF}^{\mathrm{b}}$ & $\mathrm{PR}^{\mathrm{c}}$ & Phenotype $^{\mathrm{d}}$ \\
\hline M. exigua E1 & 5 & $101.5 \mathrm{a}$ & 5 & $105.0 \mathrm{a}$ & 0 & HS \\
\hline M. exigua E2 & 5 & $45.2 \mathrm{~b}$ & 5 & $53.9 \mathrm{~b}$ & 0 & HS \\
\hline M. paranaensis & 5 & $26.1 \mathrm{c}$ & 4 & $18.3 \mathrm{c}$ & 30 & S \\
\hline M. incognita race 1 & 5 & $55.4 \mathrm{~b}$ & 2 & $7.8 \mathrm{~d}$ & 86 & MR \\
\hline M. incognita race 2 & 5 & $58.5 \mathrm{~b}$ & 2 & $6.6 \mathrm{~d}$ & 89 & MR \\
\hline M. incognita race 3 & 5 & $47.5 \mathrm{~b}$ & 2 & $6.2 \mathrm{~d}$ & 87 & MR \\
\hline
\end{tabular}

\footnotetext{
${ }^{\text {a }}$ Mean value of Gall index

${ }^{\mathrm{b}}$ Mean value of reproduction factor. Different lower-case letters indicate significance at $P<0.05$ according to the Scott and Knott (1974) test

${ }^{\mathrm{c}}$ Percentage of population reduction

${ }^{\mathrm{d}}$ Based on the scale of Moura and Regis (1987) HS = highly susceptible, $\mathrm{S}=$ susceptible, MR = moderately resistant
} 
Fig. 1 Sections from roots of C. arabica cv. 'IAC 15' (susceptible control) infested with $M$. incognita race 1. a localization of a J2 in the root cortex near the vascular central cylinder (2 DAI). Bar $=10 \mu \mathrm{m}$; b highly vacuolated giant cells surrounding the nematode within the central cylinder (6 DAI). Bar $=20 \mu \mathrm{m}$; c gall containing giant cells with a dense cytoplasm and large vacuoles (arrowheads) and a nematode (8 DAI). Bar $=20 \mu \mathrm{m}$; d feeding site containing several nematodes (14 DAI). Bar $=40 \mu \mathrm{m}$; e, f galls containing females compressing the parenchyma as indicated by arrowheads (34 DAI and 49 DAI, respectively). $\mathrm{Bar}=20 \mu \mathrm{m}$. (d, f) Sections were visualized under UV and (a-e) bright field after blue toluidine staining. $\mathrm{Ne}=$ nematode, $\mathrm{GC}=$ giant cells, $\mathrm{cc}=$ central cylinder. Xylem elements appear in blue (toluidine) or white (UV)
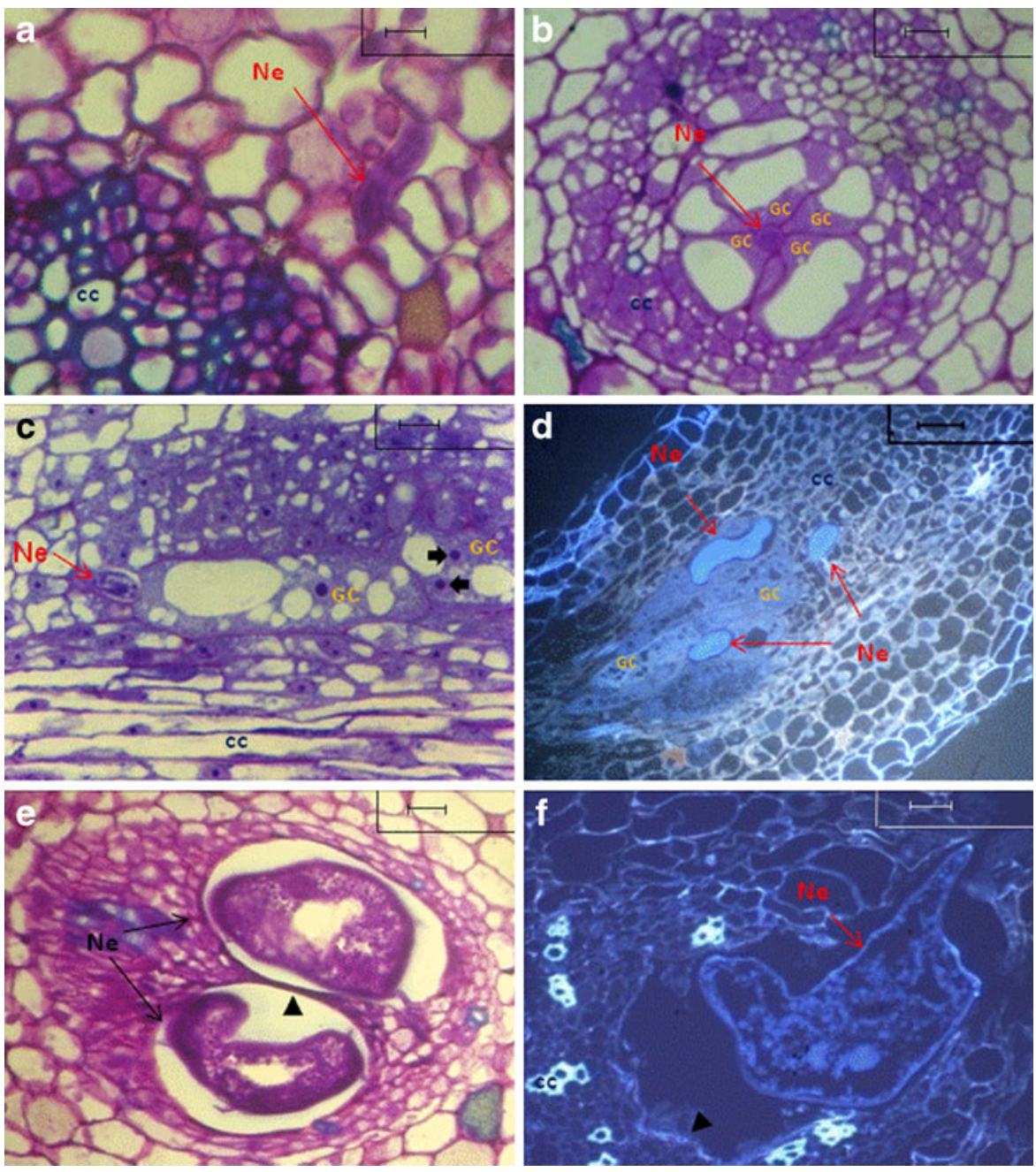

molted to J3/J4 before becoming females. Galls containing females were observed around 34 DAI and were located inside the central cylinder. Growth of females caused mechanical damage of parenchyma and vascular tissue, marked by the presence of darkstained tissues and collapsed cells (Fig. 1e). At 49 DAI, the development of females caused the cracking of the root cortex, finally exposing the egg masses to the exterior of the infected root.

\section{Incompatible interaction}

Whilst nematode infection of 'UFV 408-28' at 2 DAI and 4 DAI was not observed by microscopy in the fixed root samples, and rarely detected by macroscopic observation of fuchsine stained roots, after 6 DAI, many $\mathrm{J} 2$ were visible by microscopy forming clusters in the root apex (Fig. 2a). Microscopic observations of the 'UFV 408-28' -infected samples at similar time points showed that nematodes were able to reach the vascular cylinder but no gall induction was observed (10 DAI). From approximately 4,500 resistant root sections analyzed from 2 to 34 DAI, neither giant cell induction nor feeding site establishment was observed. Moreover, only the J2 stage was detected, indicating that the great majority of the invading nematodes were not able to molt into more advanced stages of development in the resistant roots.

Fluorescence microscopy using UV excitation of root sections harvested at 6-8 DAI showed a strong yellow autofluorescence around the nematodes in all infection sites examined (Fig. 2c, f). The same sections visualized under bright field after toluidine 
Fig. 2 Sections from roots of C. arabica 'UFV408-28' (resistant genotype) infested with $M$. incognita race 1 . a Numerous juvenile nematodes inside the root tip (3 DAI). Bar $=20 \mu \mathrm{m} ; \mathbf{b}$ root apex containing infecting nematodes (6 DAI).

Bar $=40 \mu \mathrm{m}$; c juveniles invading the sub-apical area of the root. Host cells close to the nematode display necrotic-like features, characterized by yellow autofluorescence (7 DAI). Bar $=15 \mu \mathrm{m}$; d juveniles inside dark-stained material from necrotic like host cells, close to xylem vessels (8 DAI). Bar $=5 \mu \mathrm{m}$; e, f Juveniles surrounded by necrotic cells (8 DAI). f autofluorescence corresponding to necrotic sites. Bar $=150 \mu \mathrm{m}$. (c, f) Sections were visualized under UV and (b, d, e) bright field after blue toluidine or (a) fucsine staining. $\mathrm{Ne}=$ nematode, $\mathrm{cd}=$ cell death, arrowheads $=$ HRlike autofluorescent material. Xylem elements appear in blue (toluidine) or white (UV)
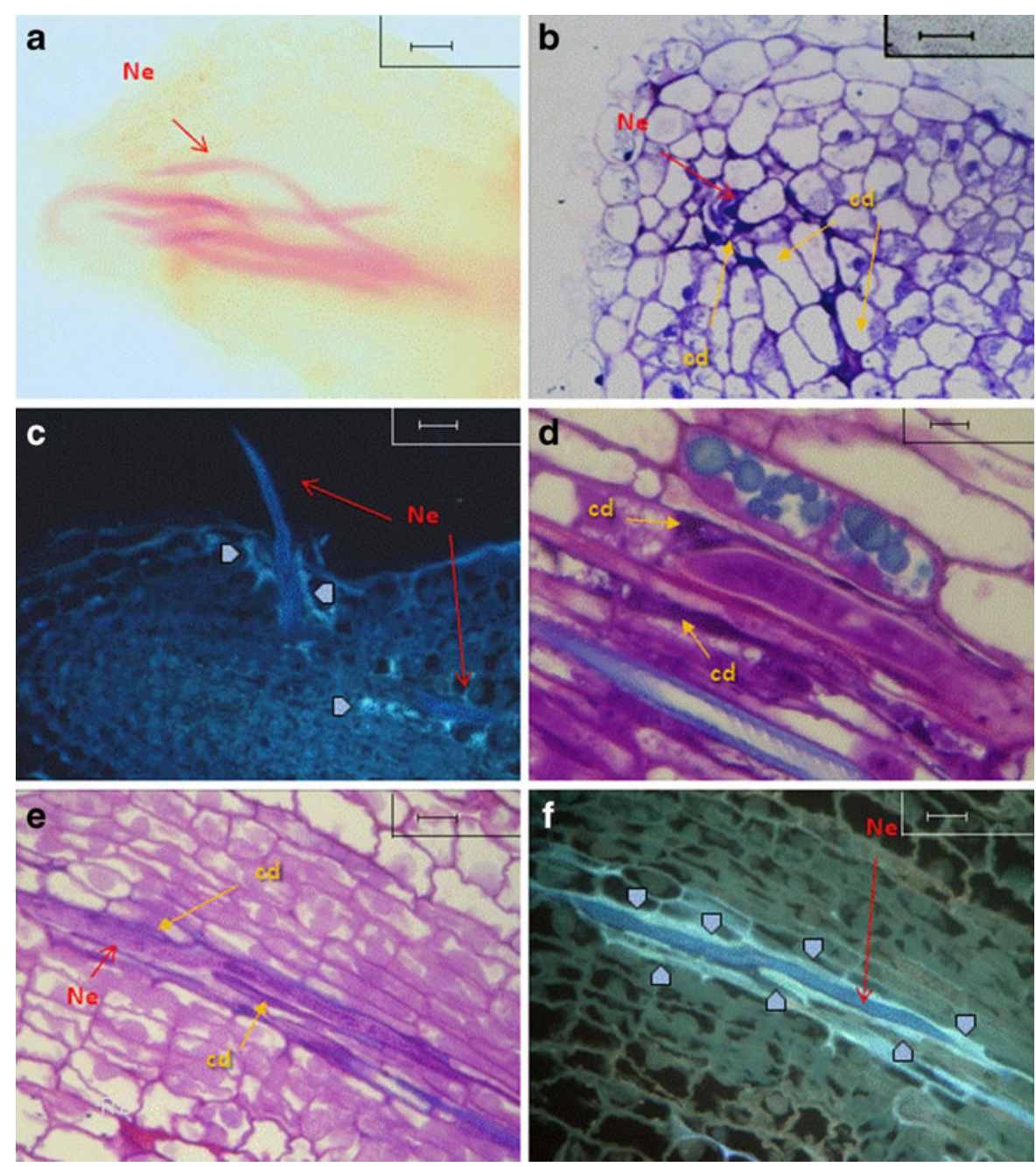

staining showed a purple coloring, indicating necrosis of the cells in contact with the nematodes. (Fig. 2d, e). These HR-like lesions were found around all nematodes after they penetrated the epidermis (Fig. 2c) or migrated through the cortex (Fig. 2b, e, and f) or when they reached the vascular cylinder (Fig. 2d). Some longitudinal sections contained almost entire bodies of nematodes completely surrounded by autofluorescence or toluidine dark-stained components (Fig. 2e and f).

\section{Discussion}

In the current study, characterization of the $C$. arabica genotype 'UFV 408-28' showed that this strain was moderately resistant to $M$. incognita races
1, 2 and 3 (Table 1), and displayed an HR-like phenotype upon $M$. incognita race 1 infection (Fig. 2c-f). By contrast, 'UFV 408-28' was susceptible to $M$. paranaensis and highly susceptible to $M$. exigua (Table 1). This suggests that the resistance to $M$. incognita is controlled by specific gene(s) in 'UFV 408-28'.

M. incognita races 1, 2 and 3 showed low GI and RF in UFV408-28. The resistance of 'UFV 408-28' to $M$. incognita was confirmed and characterized at the histological level. Many J2 penetrated the resistant genotype, but none developed further, therefore J3/J4 or female stages were never detected in infected roots. HR-like symptoms were detected during nematode infection in resistant roots. Necrosis of plant cells in contact with penetrating or migrating juveniles were clearly found in sections of roots at 6 to 8 DAI and 
probably resulted in the arresting of nematode development. This finding suggests that an active defence system may operate upon $M$. incognita penetration in the 'UFV 408-28' roots to prevent nematode development and reproduction.

The timing and localization of the resistance response differ according to the type of plantpathogen interaction. In pepper (Capsicum annuum), Pegard et al. (2005) showed by comparative histological studies that the three broad-spectrum resistance genes $\left(\mathrm{Me}_{1}, \mathrm{Me}_{3}\right.$ and $\left.\mathrm{Me}_{7}\right)$ induced different response patterns to nematode infection, therefore distinct histological responses. Observed HR responses of different pepper lines harbouring the different $\mathrm{Me}$ genes apparently blocked most of migrating nematodes when entering the epidermis (1 DAI), or later in the cortex (up to 5 DAI; Pegard et al., 2005). In coffee, the HR triggered by M. exigua infection in the Mexl-carrying genotype IAPAR59 did not prevent formation of a few giant cells but nematodes and feeding sites did not develop further (Anthony et al. 2005). In the 'UFV 408-28'-M. incognita interaction, no giant cells were recorded but the HR could be observed around a number of nematodes which succeeded in arriving at the vascular cylinder (Fig. 2d), indicating that the plant immunity system was not fully efficient in suppressing all infective J2 penetration and migration. Eventhough no females were found in sections of roots of 'UFV 408-28', a low RF was still recorded for $M$. incognita race 1 in this genotype during infection tests. Although never observed in sections, some juveniles were able to develop, considering that few galls and eggs were recorded 8 months after inoculation. No 'UFV 408-28' roots containing developing nematodes were sampled because the population was very low after the first cycle and few $M$. incognita J2 overcame the resistance after eight cycles. It is also possible that some $C$. arabica individuals from the progeny analyzed were heterozygous for the resistance trait due to open pollination.

In the compatible interaction between 'IAC 15' and $M$. incognita race 1 , juveniles induced welldefined feeding sites (Fig. 1b-d). As already stated by Vovlas and Di Vito (1991), giant cells induced by $M$. incognita were undersized when compared with the $C$. arabica cells induced by $M$. exigua infection (Anthony et al. 2005) although feeding cells were similar to M. incognita infection in tomato (Bird
1961). The presence of one large vacuole was evident, accompanied by other smaller ones compressing the cytoplasm and nuclei to the periphery of giant cells. Nuclei had an irregular shape, while nucleoli were round as described for the $M$. exigua infection of $C$. arabica, in contrast to the nuclear ultrastructural changes reported when coffee roots were infected with M. megadora (Rodrigues et al. 2000). At 34 DAI, females were located inside the central cylinder (Fig. 1e) and caused mechanical damage to the root tissues, as described by Negron and Acosta (1987). The complete life cycle observed under greenhouse conditions $\left(20-25^{\circ} \mathrm{C}\right)$ was around 40 days. This is similar to the evaluation of eleven generations per year obtained in coffee plants as described by Jaehn (1991) for M. incognita race 1.

Among the $R$ genes conferring resistance against plant parasitic nematodes, $M i-1$ is the only cloned gene conferring resistance to a Meloidogyne species (Vos et al. 1998). Mi-1.2 mediated resistance is characterized by a rapid localized cell death that occurs near the anterior end of the nematode in the region of the root where feeding site initiation occurs (Williamson 1999). In nematode-resistant tomatoes, neither a feeding site is established nor do nematodes develop. Nematode resistance is clearly associated with HR symptoms, but whether this response is a cause or consequence remains unclear (Williamson and Kumar 2006). In coffee, the HR of 'UFV 40828 ' root cells triggered upon $M$. incognita infection may be indicative of a specific gene-for-gene recognition system between the host plant and the parasite. This would suggest that the 'UFV 408-28' resistance to $M$. incognita is controlled by a resistance gene that could be used to produce new coffee varieties resistant to $M$. incognita. A segregating population has been built for mapping and further investigation of the resistance gene(s) that could control the 'UFV 408-28'-M. incognita interaction. Improvement of coffee plants to achieve RKN resistance is vital for most of the producing countries and could be even more urgent in the near future, according to risk analysis studies on climate changes (Ghini et al. 2008). Traditional breeding programs usually rely on the related diploid species C. canephora or C. racemosa as sources of resistance to RKN (Maluf 2008). However, the crossing limitations of this strategy demand elevated costs and long-term investments to develop new Arabica 
cultivars combining good cup quality and resistance to parasites. Using the tetraploid Arabica 'UFV 408-28' genotype as donor would greatly facilitate resistance gene transfer to elite susceptible coffee varieties.

The C. arabica 'UFV 408-28' genotype resistant to $M$. incognita races 1, 2 and 3 could also be useful as a model for studying host-nematode relationships in perennial plants. Recent studies showed that nematodes secrete specific effector proteins to manipulate the host plant during infection. Several putative virulence effectors have already been identified in $M$. incognita (Bellafiore et al. 2008). However, the study of $M$. incognita avirulence effectors is limited by the availability of suitable $R$-gene mediated incompatible interactions. The interaction between coffee and $M$. incognita could also be a promising alternative to the tomato $\mathrm{Mi}$-mediated resistance system for the molecular analysis of plant-nematode incompatible interactions in perennial crops.

Acknowledgements We thank Dr M. Eira (Embrapa, Brazil) for assistance in preservation and germination of grains, and Dr. L. Villain (Cirad, France) for manuscript reviewing. This work was funded by Consórcio Brasileiro de Pesquisa e Desenvolvimento do Café, Embrapa, UCB, CNPq and CAPES-Cofecub (project Sv 555/07).

\section{References}

Anthony, F., Topart, P., Martinez, A., Silva, M., Nicole, M., \& Silva, A. R. (2005). Hypersensitive-like reaction conferred by the Mex-1 resistance gene against Meloidogyne exigua in coffee. Plant Pathology, 54, 476-482.

Bellafiore, S., Shen, Z., Rosso, M.-N., Abad, P., Shih, P., \& Briggs, S. (2008). Direct identification of the Meloidogyne incognita secretome reveals proteins with host cell reprogramming potential. Public Library of Science Pathology, 4 (10), e1000192. doi:10.1371/journal.ppat.1000192.

Bertrand, B., \& Anthony, F. (2008). Genetics of resistance to root-knot nematodes (Meloidogyne spp.) and breeding. In R. M. Souza (Ed.), Plant-parasitic nematodes of coffee (pp. 165-190). Berlin: Springer.

Bertrand, B., Aguilar, G., Bompard, E., Rafinon, A., \& Anthony, F. (1997). Comportement agronomique et résistance aux principaux déprédateurs des lignées de Sarchimor et Catimor au Costa Rica. Plantations Recherche Développement, 4, 312-321.

Bird, A. F. (1961). The ultrastructure and histochemistry of a nematode-induced giant cell. Journal of Biophysical and Biochemical Cytology, 11, 701-715.

Bird, D. M., \& Kaloshian, I. (2003). Are roots special? Nematodes have their say. Physiological and Molecular Plant Pathology, 62, 115-123.
Boneti, J. I. S., \& Ferraz, S. (1981). Modificação do método de Hussey \& Barker para extração de ovos de Meloidogyne incognita de raízes de cafeeiros. Fitopatologia Brasileira, 6, 553.

Byrd, J. D. W., Kirkpatrick, J., \& Barker, K. R. (1983). An improved technique for clearing and staining plant tissues for detection of nematodes. Journal of Nematology, 15, 142-143.

Campos, V. P., \& Villain, L. (2005). Nematode parasites of coffee and cocoa. In M. Luc, R. Sikora, \& J. Bridge (Eds.), Plant parasitic nematodes in subtropical and tropical agriculture (pp. 529-579). Wallingford: CAB International.

Carneiro, R. M. D. G., \& Almeida, M. R. A. (2001). Técnica de eletroforese usada no estudo de enzimas dos nematóides de galhas para identificação de espécies. Nematologia Brasileira, 25, 34-44.

Das, S., DeMason, D. A., Ehlers, J. D., Close, T. J., \& Roberts, P. A. (2008). Histological characterization of root-knot nematode resistance in cowpea and its relation to reactive oxygen species modulation. Journal of Experimental Botany, 59, 1305-1313.

Fuller, V. L., Lilley, C. J., \& Urwin, P. E. (2008). Nematode resistance. New Phytologist, 180, 27-44.

Ghini, R., Hamada, E., Júnior, M. J. P., Marengo, J. A., \& Gonçalves, R. R. V. (2008). Risk analysis of climate change on coffee nematodes and leaf miner in Brazil. Pesquisa Agropecuária Brasileira, 43, 187-194.

Hartman, K. M., \& Sasser, J. N. (1985). Identification of Meloidogyne species on the basis of differential host test and perineal-pattern morphology. In K. R. Barker, C. C. Carter, \& J. N. Sasser (Eds.), Advanced treatise on meloidogyne (pp. 69-77). Raleigh: North Carolina State University.

Hunt, D. J., Luc, M., Manzanilla-López, R. H. (2005). Identification, morphology and biology of plant parasitic nematodes. In M. Luc, R. Sikora, J. Bridge (Eds.), Plant parasitic nematodes in subtropical and tropical agriculture (pp. 11-52). Wallingford: CAB International.

Hussey, R. S., \& Baker, K. R. (1973). A comparison of methods of collecting inocula of Meloidogyne spp. including a new technique. Plant Disease Reporter, 57, 1025-1028.

Jaehn, A. (1991). Estimativa do número de gerações de três raças de Meloidogyne incognita em cafeeiro para o estado de São Paulo. Nematologia Brasileira, 15, 143-151.

Jones, J. D., \& Dangl, J. L. (2006). The plant immune system. Nature, 444, 323-329.

Lam, E., Kato, N., \& Lawton, M. (2001). Programmed cell death, mitochondria and the plant hypersensitive response. Nature, 411, 848-853.

Maluf, M. P. (2008). Genomic tools for the development of engineered Meloidogyne-resistant coffee cultivars. In R. M. Souza (Ed.), Plant-parasitic nematodes of coffee (pp. 191-205). Berlin: Springer.

Moura, R., \& Regis, E. M. O. (1987). Reações de cultivares de feijoeiro comum (Phaseolus vulgaris) em relação ao parasitismo de Meloidogyne javanica e M. incognita. Nematologia Brasileira, 11, 215-225.

Negron, J., \& Acosta, N. (1987). Studies on host-parasite relashionships of Meloidogyne incognita and Coffea arabica cv Borbon. Nematropica, 14, 71-78. 
Noir, S., Anthony, F., Bertrand, B., Combes, M. C., \& Lashermes, P. (2003). Identification of a major gene (Mex-1) from Coffea canephora conferring resistance to Meloidogyne exigua in Coffea arabica. Plant Pathology, 52, 97-103.

Pegard, A., Brizzard, G., Fazari, A., Soucaze, O., Abad, P., \& Djian-Caporalino, C. (2005). Histological characterization of resistance to different root-knot nematode species related to phenolics accumulation in Capsicum annuum. Phytopathology, 95, 158-165.

Proite, K., Carneiro, R., Falcao, R., Gomes, A., Leal-Bertioli, S., Guimaraes, P., et al. (2008). Post-infection development and histopathology of Meloidogyne arenaria race 1 on Arachis spp. Plant Pathology, 57, 974-980.

Randig, O., Bongiovanni, M., Carneiro, R. M. D. G., \& Castagnone-Sereno, P. (2002). Genetic diversity of rootknot nematodes from Brazil as inferred from RAPD analysis and development of SCAR markers specific for the coffee damaging species. Genome Research, 45, 862-870.

Roberts, P. A., \& May, D. M. (1986). Meloidogyne incognita resistance characteristics in tomato genotypes developed for processing. Journal of Nematology, 18, 383-359.

Rodrigues, A., Abrantes, I. M. D., Melillo, M. T., \& BleveZacheo, T. (2000). Ultrastructural response of coffee roots to root-knot nematodes, Meloidogyne exigua and $M$. megadora. Nematropica, 30, 201-210.
Scott, A. J., \& Knott, M. A. (1974). A cluster analysis method for grouping means in the analysis of variance. Biometrics, 30, 507-512.

Trudgill, D. L. (1997). Parthenogenetic root-knot nematodes (Meloidogyne spp.); how can these biotrophic endoparasites have such an enormous host range? Plant Pathology, 46, 26-32.

Vos, P., Simons, G., Jesse, T., Wijbrandi, J., Heinen, L., Hogers, R., et al. (1998). The tomato Mi-1 gene confers resistance to both root-knot nematodes and potato aphids. Nature Biotechnology, 16, 1365-1369.

Vovlas, N., \& Di Vito, M. (1991). Effect of root-knot nematodes Meloidogyne incognita and M. javanica on the growth of coffee (Coffea arabica L.) in pots. Nematoloia mediteranea, 19, 253-258.

Whitehead, A. G., \& Heming, J. R. (1965). A comparison of some quantitative methods of extracting small vermiform nematodes from soil. Annals of Applied Biology, 55, 25-38.

Williamson, V. M. (1999). Plant nematode resistance genes. Current Opinion in Plant Biology, 2, 327-331.

Williamson, V. M., \& Hussey, R. S. (1996). Nematode pathogenesis and resistance in plants. Plant Cell, 8, 1735-1745.

Williamson, V. M., \& Kumar, A. (2006). Nematode resistance in plants: the battle underground. Trends in Genetics, 22, 396- 403 . 